\title{
Application of Wharton jelly-derived mesenchymal stem cells in patients with pulmonary fibrosis
}

\author{
Mahshid Saleh ${ }^{1 *}$, Seyedeh Zahra Fotook Kiaei ${ }^{2}$ and Maria Kavianpour ${ }^{1}$
}

\begin{abstract}
Pulmonary fibrosis is a devastating disease that eventually leads to death and respiratory failure. Despite the wide range of drugs, including corticosteroids, endothelin antagonist, and pirfenidone, there is no effective treatment, and the only main goal of treatment is to alleviate the symptoms as much as possible to slow down the progression of the disease and improve the quality of life. Lung transplantation may be a treatment option for a few people if pulmonary fibrosis develops and there is no established treatment. Pulmonary fibrosis caused by the COVID19 virus is another problem that we face in most patients despite the efforts of the international medical communities. Therefore, achieving alternative treatment for patients is a great success. Today, basic research using stem cells on pulmonary fibrosis has published promising results. New stem cell-based therapies can be helpful in patients with pulmonary fibrosis. Wharton jelly-derived mesenchymal stem cells are easily isolated in large quantities and made available for clinical trials without causing ethical problems. These cells have higher flexibility and proliferation potential than other cells isolated from different sources and differentiated into various cells in laboratory environments. More clinical trials are needed to determine the safety and efficacy of these cells. This study will investigate the cellular and molecular mechanisms and possible effects of Wharton jelly-derived mesenchymal stem cells in pulmonary fibrosis.
\end{abstract}

Keywords: Stem cell, WJ-MSC, Pulmonary fibrosis, Cell-based therapy

\section{Introduction}

The lung organ is located in the chest, where the delicate lung tissue is protected by the bony and muscular cage of the chest. This tissue provides a constant flow of oxygen to the human body's tissues, and in the meantime, the blood is cleared of carbon dioxide. Air is regularly pumped in and out through air ducts. The airways are divided into upper and lower airway systems. The transmission between the two air systems is located above the larynx [1]. Tissue fibrosis and its failure are significantly associated with mortality worldwide [2]. Fibrosis is

\footnotetext{
*Correspondence: m saleh@razi.tums.ac.ir

${ }^{1}$ Department of Applied Cell Sciences, School of Advanced Technologies in Medicine, Tehran University of Medical Sciences, Tehran, Iran

Full list of author information is available at the end of the article
}

defined by excessive deposition of connective tissue components, including myofibroblasts [3]. Fibrotic disease is usually characterized by a progressive and incomplete cycle of abnormally high accumulation of myofibroblasts [2]. It can affect almost all tissues. In this disease process, the affected organs lose their physiological function and become defective [3]. When the injury occurs, tissue microenvironmental regeneration is critical to restoring normal organ function. Inflammation and subsequent acute inflammatory reactions for various reasons, including infection or injury, can disrupt epithelial and endothelial integrity and lead to complications such as edema, leukocyte uptake, and angiogenesis. Regeneration of damaged tissue and elimination of inflammation through apoptotic and phagocytic pathways often leaves minimal damage. However, the presence of a persistent original author(s) and the source, provide a link to the Creative Commons licence, and indicate if changes were made. The images or other third party material in this article are included in the article's Creative Commons licence, unless indicated otherwise in a credit line to the material. If material is not included in the article's Creative Commons licence and your intended use is not permitted by statutory regulation or exceeds the permitted use, you will need to obtain permission directly from the copyright holder. To view a copy of this licence, visit http://creativecommons.org/licenses/by/4.0/. The Creative Commons Public Domain Dedication waiver (http://creativeco mmons.org/publicdomain/zero/1.0/) applies to the data made available in this article, unless otherwise stated in a credit line to the data. 
inflammation can cause idiopathic pulmonary fibrosis (IPF) $[4,5]$.

\section{Pulmonary fibrosis (PF)}

Pulmonary fibrosis is characterized by damage to the alveolar epithelial cells, regeneration of lung tissue, an unusual accumulation of extracellular matrix, and fibroblasts in the tissue [6,7], which leads to respiratory failure and death [8]. When inflammation predominates, a pathogenic fibrotic reaction occurs, during which angiogenic, proinflammatory, fibrosis-causing cytokines, destructive enzymes, and growth factors accumulate at the injury site $[4,9]$. The most common type of pulmonary fibrosis, idiopathic pulmonary fibrosis (IPF), is a progressive disease of the lower respiratory tract with a 5-year survival rate that usually affects adults over 40 years of age [10, 11]. The factors involved in the onset of histopathological cascade in pulmonary fibrosis (PF) are unknown [12, 13]. PF-related risk factors in three categories of comorbidities, internal and external risk factors, are listed in Table 1 [14-18].

\section{Pathophysiology of pulmonary fibrosis}

Pulmonary fibrosis has resulted from recurrent damage to lung tissue leading to epithelial damage followed by the destruction of the alveolar-capillary basement membrane. This process causes fibroblast cells to infiltrate and myofibroblasts to become active. Eventually, the lung tissue loses its function and progresses to death [13]. Studies have shown that alveolar epithelial cell damage is an essential factor in the pathogenesis of idiopathic pulmonary fibrosis. Studies have reported type 2 alveolar cell (ATII) hyperplasia in patients with IPF [19]. In familial forms of pulmonary fibrosis, mutations in genes involved in tissue regeneration lead to damage or apoptosis of ATII cells [20]. ATII cells damage leads to ineffective reconstitution of normal epithelium and fibrosis development with activation of myofibroblasts [21, 22]. Repeated damage to the alveolar region creates a pro-inflammatory environment [2]. Inflammation leads to an abnormal

Table 1 Risk factors in pulmonary fibrosis

\begin{tabular}{lll}
\hline External risk factors & Internal risk factors & Co-morbidities \\
\hline Cigarette smoking & Genetics & Gastroesophageal reflux \\
$\begin{array}{l}\text { Environmental pollut- } \\
\text { ants }\end{array}$ & Aging & Obstructive sleep apnea \\
Air pollution & Sex & Diabetes mellitus \\
Drugs & Lung microbiome & Virus infection \\
Certain occupations & & Chronic aspiration \\
Cancer treatments & & \\
(radiation treatments) & & \\
\hline
\end{tabular}

wound healing response explained by genetic changes in crucial genes such as TGFb1, tumor necrosis factor-alpha (TNFo), MCP1/CCL2, MIP1a/CCL3, and surfactant protein C (SFTPC) [2, 23, 24].

TNF- $\alpha$ is a pleiotropic cytokine produced by a variety of cells in response to infection or damage. Improper secretion of TNF is involved in the pathogenesis of various human diseases, including infection, transplant rejection, cancer, inflammatory diseases, and pulmonary fibrosis $[25,26]$. This cytokine plays an essential role in cell adhesive, inflammatory responses, migration, and activation of cytokine and chemokine cascades [27].

One of the most substantial profibrotic factors is TGFb, which promotes lung fibrosis by using and activating monocytes and fibroblasts and producing an extracellular matrix. TGF-b1 induces fibroblast proliferation by inducing fibroblast growth factor 2 and subsequent activation of the MAPK signaling pathway [28], leading these cells to differentiate into myofibroblasts. TGF-b promotes ECM production by promoting ECM gene transcription [29]. The proinflammatory chemokines MCP1 / CCL2 and MIP1a / CCL3 are among the monocyte invoking chemokines [30]. Macrophages and fibroblasts express CCL2 / MCP-1, and its production is required for pulmonary fibrosis [31]. CCL3 / MIP-1a also helps to aggravate lung damage [32]. Studies have shown that in the BAL secretions of patients with IPF, the levels of CCL2 / MCP-1 and CCL3 / MIP-1a were increased compared to healthy individuals $[33,34]$.

\section{Wharton jelly-derived mesenchymal stem cells}

Mesenchymal stem cells are multipotent progenitor cells that can proliferate and regenerate [35]. Mesenchymal cells, like ready-made soldiers, are found in all types of adult tissues, including bone marrow, fat, skin, placenta, and heart, which migrate easily through the blood vessels when damaged by the secretion of various inflammatory factors and the invocation of inflammatory cells. Due to its surface receptors, it implants with SDF1 factors secreted from the affected area and controls the immune system by secreting various factors [36]. Rich sources of MSCs include tissues such as the placenta, umbilical cord, amniotic fluid, and amniotic membrane, considered medical waste [37]. Compared to adult tissues, stem cells isolated from the amniotic membrane (AM), chorionic plate $(\mathrm{CP})$, peritoneal, and umbilical cord (UC) tissues have more advantages [38-40]. Umbilical Cord consists of two arteries and a vein inserted into a particular mucosal connective tissue known as Wharton jelly (WJ), which is covered by the amniotic epithelium. UC-MSC have a distinct capacity for self-renewal and the ability to differentiate into adipocytes, osteocytes, chondrocytes, neurons, and liver cells. In addition, when cells 
enter the host body, they accumulate in damaged tissue or inflamed areas and accelerate tissue repair by modulating the immune system [41, 42]. Wharton Jelly isolated from mesenchymal stem cells (hWJMSC) have been described as the best source of MSC [43]. The findings clearly show that WJ-MSC can be the best suggestion for clinical use due to its advantages such as higher proliferation and differentiation potential, easy access, easy and noninvasive separation, a large number of cells, and no ethical problems $[44,45]$. Age is an essential issue in cells isolated from the donor [46]. Young donor cells in the culture medium are less exposed to damage and oxidative changes, age much more slowly and have a higher proliferation rate than the older donor $[47,48]$. Because of such benefits, Wharton jelly-derived stem cells have received significant attention in various diseases. Mesenchymal stem cells secrete trophic factors that maintain cell survival, including stromal derived factor-1 (SDF-1), hepatocyte growth factor (HGF), and insulin-like growth factor (IGF-1), epithelial growth factor (EGF), nerve growth factor (NGF), transforming growth factor-alpha (TGF-a), and tissue angiogenesis vascular endothelial growth factor (VEGF)[49]. Also, the culture medium of WJ-MSCs contains several secretory factors such as RANTES, MCP-1, MIP-1, IL-12, IL-15, IL-6, IL-8, IL-2, and PGE2. Its immunomodulatory effects mediate through these factors [50].

\section{Immunomodulatory effects of Wharton jelly-derived mesenchymal stem cells}

According to preclinical and clinical studies performed on hWJMSC, these cells seem to be an excellent source in cell-based reconstructive medicine and clinical trials. The WJ-MSC can also suppress the immune system and modulate the immune system through cell-to-cell contact and secretion of soluble factors, thus placing them as suitable candidates for cell therapy in allogeneic transplantation [51]. WJ-MSCs show minimal human leukocyte antigen (HLA) class I antigen expression and no HLA-DR. $[52,53]$. HLA-G6 is a type of immunosuppressant produced by WJ-MSCs that inhibits the cytolytic activity of NK cells and does not express the markers CD40, CD80, or CD86 involved in T cell activation [42]. HLA- G6 is produced by trophoblasts and protects the fetus from immune-based degradation [54]. IL-6 (interleukin-6) secreted by mesenchymal stem cells isolated from the umbilical cord leads dendritic cells to tolerant phenotypes [55]. Factors such as TGF- $\beta 1$, IL-10 (interleukin 10), HGF (Hepatocyte growth factor), PGE2 (prostaglandin E2), IDO (indolamine 2, 3-dioxygenase), galactin-1 are secreted by mesenchymal stem cells. They play an essential role in regulating the immune system $[42,56]$. In addition, studies have shown increased expression of anti-inflammatory molecules such as CD200 or PD-L1 (programmed death ligand 1) in WJ-MSC mesenchymal stem cells [57].

MSC-derived exosomes prevent inflammatory cells from penetrating the injury site, reduce lung damage, reduce inflammatory cytokines such as TNF- $\alpha$ and IL-6, and multiple paracrine factors, including TNF, Angiopoietin-1, TSG-6, lipocalin-2, microRNAs, LL-37, and KGF improve survival [58-64]. Mesenchymal stem cells express the TSG- 6 gene, which mediates the regulation of immune inflammation [65]. TSG-6 is another major factor that plays a vital role in the tissue repair activity of human mesenchymal stem cells, proven in models of myocardial infarction, peritonitis, and acute corneal and lung damage in mice $[66,67]$. TSG- 6 cleaves the binding of CXCL8 to heparin by interacting with the GAGCXCL8 binding site to inhibit the delayed chemotactic effect of neutrophils mediated by CXCL8. In addition, TSG-6 can prevent the migration of leukocytes (mainly neutrophils and macrophages) to the site of inflammation [68]. During tissue damage and the formation of the primary inflammatory phase, proinflammatory macrophages (M1) are activated, clearing pathogenic microorganisms and forming inflammation through extracellular matrix metalloproteases (MMPs) and proinflammatory cytokines [69]. Increased anti-inflammatory M2 macrophages inhibit the inflammatory response produced by chemokines, MMPs, tissue metalloproteinase inhibitors (TIMPs), and fibronectin, leading to the progression of fibrotic lung disease [70-72]. MSCs can alter macrophage phenotypes from an inflammatory M1 phenotype to a more immunomodulatory M2 phenotype, thereby modulating macrophages [73, 74]. On the other hand, mesenchymal stem cells can increase IL-10 levels as an anti-inflammatory protein that activates regulatory cells such as Tregs [75]. Thus, mesenchymal stem cells play a significant role in immune homeostasis by interacting with cytokines, chemokines, and cell surface molecules.

\section{Mechanism of action of WJ-MSC on pulmonary fibrosis}

The exact mechanisms by which stem cells positively affect lung fibroids are not yet known. These mechanisms include several biological pathways, including targeted transplantation into affected areas, differentiation of stem cells into lung epithelial cells, the ability of the immune system to modulate, secretion of antiinflammatory and anti-fibrotic factors, and the ability of the lung to repair endogenously [76]. Fibroblast activation processes through the epithelium and unfavorable response to anti-inflammatory medications are involved in developing idiopathic pulmonary fibrosis [77]. This process is associated with immune responses including 
the PGE2 pathway and epithelial mesenchymal transport (EMT) regulators of WISP-1 and BMP4, which are involved in the differentiation of fibroblasts and collagen [78-80]. PGE2 is one of the TGFb-dependent fibrosis antagonists [81]. PGE2 pathways can prevent Fas L apoptosis in fibroblasts and myofibroblasts [82]. Studies show that due to the low concentration of PGE2 in the BAL secretions of pulmonary fibrosis, the physiological antifibrotic action of PGE2 is limited [83]. The cause of this decrease is not well understood [84]. However, low concentrations of PGE2 make type II alveolar cells susceptible to apoptosis [82]. Because WJ-MSC cells express high levels of immune response inhibitors, including IDO and PGE2 [54], they can be used as an alternative treatment to improve pulmonary fibrosis. Studies have highlighted the prominent role of innate and adaptive immune cell populations in the fate of myofibroblasts and fibrosis-related responses in many fibrotic diseases $[85,86]$. Immune cells, including macrophages, neutrophils, NK cell, T cells, and B cells, accumulate and become active at the site of inflammation and regulate the improvement and exacerbation of the fibrosis process in various fibrotic organs through various molecular mechanisms [87]. Inflammatory macrophages activate Th2 cells in lung tissue, and this inequality in the Th1 / Th2 immune response is essential in the pathogenesis of pulmonary fibrosis [88]. Macrophages also produce an effective source of fibrotic cytokines, including TGF-b1 and PDGF, chemokines, and proteases [89]. TGF- $\beta$ signaling is also involved in healthy lung growth and repair of lung damage [90, 91]. This factor can induce fibroblast proliferation, differentiation, migration, and production and contraction of the extracellular matrix. In the adult lung, TGF- $\beta$-mediated overexpression of Smad3 plays a vital role in the development of extensive fibrosis [92]. In a study in patients with CTD-IP (Interstitial pneumonia in connective tissue diseases), they reported a significant increase in TGF- $\beta 1$ levels with a decrease in Tregs and a decrease in the ratio of TGF- $\beta 1$ to IL- 6 , indicating an increase in endogenous TGF- $\beta 1$ which is secreted by immune cells in response to the inflammatory microenvironment. Endogenous TGF- $\beta 1$ cannot differentiate Tregs due to excessive IL- 6 secretion and leads to an imbalance between IL- 6 and TGF- $\beta 1$ in local and systemic modulation of the immune response, resulting in TGF- $\beta 1$ signaling disrupts. This study examined the paradox of the TGF- $\beta 1$ pro-fibrotic factor in stimulating $\alpha$-SMA expression and myofibroblast differentiation and showed that excessive TGF- $\beta 1$ secretion from MSC cells increased IP-10 levels in UIP-HLF (Usual interstitial pneumoniahuman primary lung fibroblasts) and the simultaneous decrease in $\alpha$-SMA expression (93). Thus, high levels of TGF- $\beta 1$ secretion by HBMSCs may be an essential mechanism involved in the therapeutic effects of MSCs in promoting the spread of Tregs in IPF patients [94, 95].

Mesenchymal stem cells migrate to the injury site through adhesion molecules such as CXCR4, VLA-4, and CD44 [96-98] and secrete soluble factors that inhibit T cells' maturation dendritic cells, reducing activation and proliferation. B cells and inhibition of cytotoxicity Natural killer cells regulate the adaptive and innate immune system [99-101]. Mesenchymal stem cells modulate macrophage phenotypes by diminishing profibrotic macrophage cells and inducing anti-fibrotic effects $[102,103]$. WJ-MSCs prevent the uptake of neutrophils into the site of inflammation by IL-6, EGF, and TGF- $\alpha$. These cells can also modulate NK cells and increase the Treg population through high levels of IGF-1 and its binding proteins [104-107]. A study in an animal model of lung damage showed that WJ-MSCs reduced inflammation and prevented the expression of TNF- $\alpha$, interferon- $\gamma$, growth factor- $\beta$, MIF, and significantly reduced collagen [108]. Studies have shown the differentiation of MSCs into lung epithelial cells in a mouse model transplanted with amniotic-derived stem cells, and the CXCR4 / SDF1 axis is thought to be involved [109]. The possible mechanism of Wharton jelly-derived mesenchymal stem cells in pulmonary fibrosis is shown in Fig. 1.

\section{Mesenchymal stem cells in animal models of pulmonary fibrosis and limitations on their use in pulmonary fibrosis}

Lately, adult stem cells, including mesenchymal stem cells (MSCs), have been used in preclinical and clinical trials studies due to their multilineage differentiation, safety, ability to migrate to damaged and inflamed tissue, and immunoregulatory effect in regenerative medicine and cell therapy in respiratory disease are desirable [110-112]. Numerous preclinical studies on animal models of pulmonary fibrosis have shown that mesenchymal stem cells can reduce inflammation, decrease fibrosis, and increase the survival rate $[99,113,114]$. A study by Moroncini et al. used hUC-MSC cells for intravenous injection in C57BL / 6 mice. This study showed that intravenous injection of two doses of MSC significantly decreased fibrosis and inflammation induced by bleomycin through inhibiting IL6-IL10-TGF $\beta$ factors, including a reduction in the set of lung M2 macrophages. UC-MSC also showed vigorous anti-fibrotic activity in vivo in the mouse model [115]. Another study showed that transplantation of MenSCs in a mouse model of pulmonary fibrosis significantly improves pulmonary fibrosis by assessing pathological lesions, collagen deposition, and inflammation. These cells also inhibit the apoptosis of MLE-12 cells by suppressing the expression of inflammatory cytokines [116]. A study on the IPF model showed that WJ-derived cells diminished AKT and MMP-2 


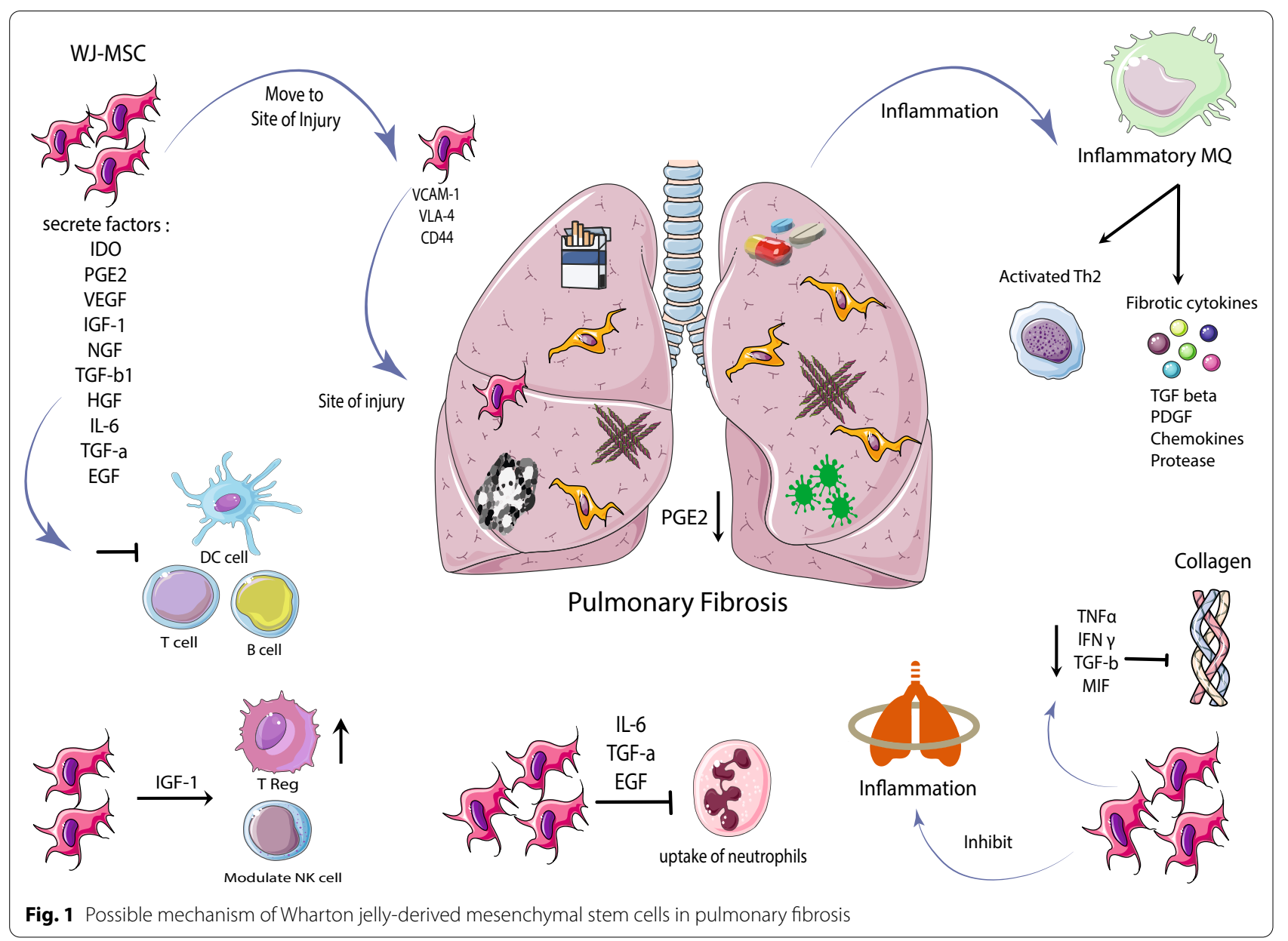

activation [114]. Another group reported that WJ-MSC represses inflammation, diminishes myofibroblast action, and enhances MMP-9 and TLR-4 receptor expression, leading to the refusal of fibrosis [117]. Because disruption of aging-related pulmonary repair tools is likely to carry the pathogenesis of IPF, the use of younger mesenchymal stem cells may have certain benefits over other sources in the treatment of BLM-induced IPF in older patient's mice [114]. The applicability of WJ-derived MSC as an anti-fibrotic in the lung has been demonstrated in these studies.

Also, in a study by Thashiro and colleagues, they examined differences between adipose mesenchymal stem cells, young and old donors, in older mice after BLM injection. This study showed that young adipose mesenchymal stem cells reduced pro-inflammatory factors, fibrosis, MMP-2 activity, oxidative stress, and apoptotic markers, but MSC treatment of older donors in BLM mice showed associated markers and fibrosis. This model did not decrease [118]. These results suggest that these cells have age-dependent anti-fibrotic properties. It can be said that the age of donors in pulmonary fibrosis is an important issue that should be considered in cellbased clinical trials in IPF patients [76]. Therefore, the use of Wharton jelly-derived mesenchymal stem cells as a young source can provide promising results in patients with pulmonary fibrosis. In the meta-analysis article on animal models of pulmonary fibrosis, 1120 articles were included. In this study, the survival rate, the effect of MSC cells on different models of pulmonary fibrosis, type of MSC, injection route, and injection time were investigated. This study showed that MSC therapy is a safe and effective technique that can significantly ameliorate the survival and pulmonary fibrosis of animal models of pulmonary fibrosis, and this study is the basis for further clinical studies [119].

Today, animal models are used for therapeutic interventions in various diseases. However, these models face limitations. One of the most widely used models for studying pulmonary fibrosis is the BLM model. This animal model is considered an IPF characteristic due to its remarkable resemblance to human idiopathic fibrosis $[120,121]$. However, the BLM model does not cover all aspects of human disease, mainly due to the progression 
of fibrosis; the ability to transfer preclinical data to clinical trials is limited [76]. Although the lungs of patients with IPF are in some cases resemble the fibrotic lungs of these animals, they are not precisely equivalent to humans in the current veterinary classification of fibrotic lung disease, they are not precisely equivalent to humans in the current veterinary classification of fibrotic lung disease [122]. In addition, most therapeutic compounds have been tested on young animals, while studies have clearly shown that older mice are more prone to pulmonary fibrotic damage than younger mice [123].

Regarding efficacy, it can be said that the preclinical efficacy of most anti-fibrotic agents, which are usually tested in the BLM-induced model, is not clinically relevant based on histological examination. Also, the majority of cases in animal studies are not blind interventions for investigators [122]. Also, cases such as the non-reproducibility of experiments between different laboratories and the size of selected animals to produce robust and clinically generalizable data can undermine the validity of experimental studies [122]. Therefore, designing clinical trial studies can help improve the quality of pulmonary fibrosis studies in these patients in the future.

\section{Clinical trial in the field of cell therapy using mesenchymal stem cells in pulmonary fibrosis}

Currently, different cells are used worldwide, including MSCs of allogeneic and autologous origin, from various adipose tissues, placenta, umbilical cord, Wharton jelly, dental pulp and menstrual, NK cell, and Tcell [124]. The safety and efficacy of mesenchymal stem cells to reduce inflammatory lung disease have been shown in animal models [125]. All reports showed that stem cell injections were safe in human clinical trials. Although the effects of cell therapy are not uniform, in some studies, its positive effects have been expressed, and in other studies, these effects have not been observed [126]. The primary purpose of most of these studies is to determine the safety, feasibility, and tolerability of injected mesenchymal stem cells in patients. In a phase 1 study in patients with idiopathic pulmonary fibrosis, adipose-derived stromal cells were used. In this study, ADSCs cells were isolated autologously and injected intrabronchially at $0.5 \times 106 \mathrm{~kg}$ body weight. The results of this study showed that no cases of severe or clinically significant long-term and short-term adverse events, including injection toxicity and abnormal tissue formation in patients, were recorded. This study also showed that intrabronchial injection of adiposederived autologous stromal cells is safe in these patients [127]. Campo and colleagues used bone marrow-derived mesenchymal stem cells in mild to moderate pulmonary fibrosis patients. In this study, $10 \times 10^{6}, 50 \times 10^{6}$, and $100 \times 10^{6}$ cells were injected intrabronchially into
13 patients as a single dose. The results showed that endobronchial infusion of BM-MSCs did not cause serious side effects in patients, but a related proportion of patients progressed clinically. Autologous use of MSCs for three patients appears to be troublesome due to MSC BM-BM genomic instability [128]. In another study, MSC cells in 9 patients with pulmonary fibrosis were injected intravenously with 20,100 , or $20010^{6}$ cells as a single dose. The results of this trial showed that human mesenchymal stem cell injections are safe in patients with IPF [129]. CHAMBERS et al. used placental-derived mesenchymal stem cells in 8 patients with IPF. In four patients, $1 \times 10^{6}$ and four patients, $2 \times 10^{6}$ cells were injected intravenously, and patients were monitored for six months. This study showed that intravenous injection of these cells was safe, and there was no evidence of worsening fibrosis [111]. Placenta-derived mesenchymal stem cells have received more attention today than other sources due to their ease of isolation and proliferation. In another study by Averyanov et al., 20 patients with idiopathic pulmonary fibrosis with reduced pulmonary function were selected. MSC cells were injected intravenously with $2 \times 10^{8}$ cells in two doses every three months. In these patients, no serious side effects were observed with the injection of cumulative doses of MSC. Lung function improved during the treatment period in these patients, and DLCO, FVC, and 6MWD parameters showed significant improvement [130].

In the meantime, clinical trial studies using mesenchymal stem cells in pulmonary fibrosis have been recorded at https://clinicaltrials.gov/, which is shown in Table 2.

\section{Possible disadvantages of using MSCs in clinical trials}

The use of new therapies such as cell therapy always has advantages and disadvantages and faces various challenges. One of the critical things in using stem cells is the tumorigenic power of these cells. The risk associated with tumorigenesis after stem cell transplantation is controversial and has been evaluated in various studies. Stem cells, like tumor cells, can proliferate for a long time, have high viability, and are resistant to apoptosis [131]. In general, donor age, recipient tissue, and growth regulators can affect transplanted mesenchymal stem cells [132, 133]. In patients undergoing long-term chemotherapy and radiotherapy, because of the immune system inadequacy, transplantation of these cells increases the risk of tumorigenesis for the patient [134]. In addition, there is a piece of evidence that the appropriate number of these cells does not reach the desired location. An insufficient number of cells reach the injury site due to their short survival and the entrapment of most of these cells after intravenous injection into the lungs [135-137]. Problems such as alloimmunization may result in the re-injection 


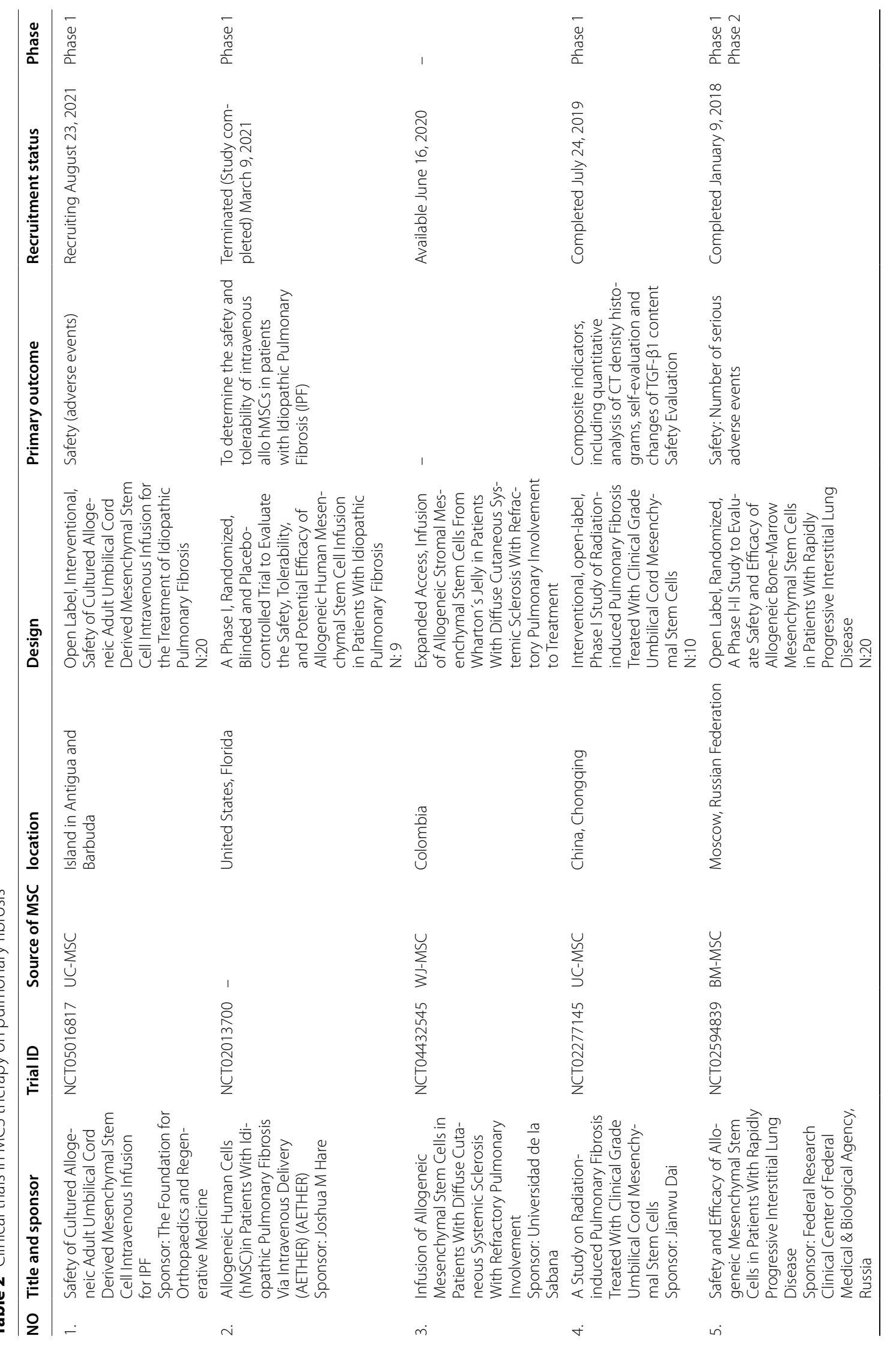




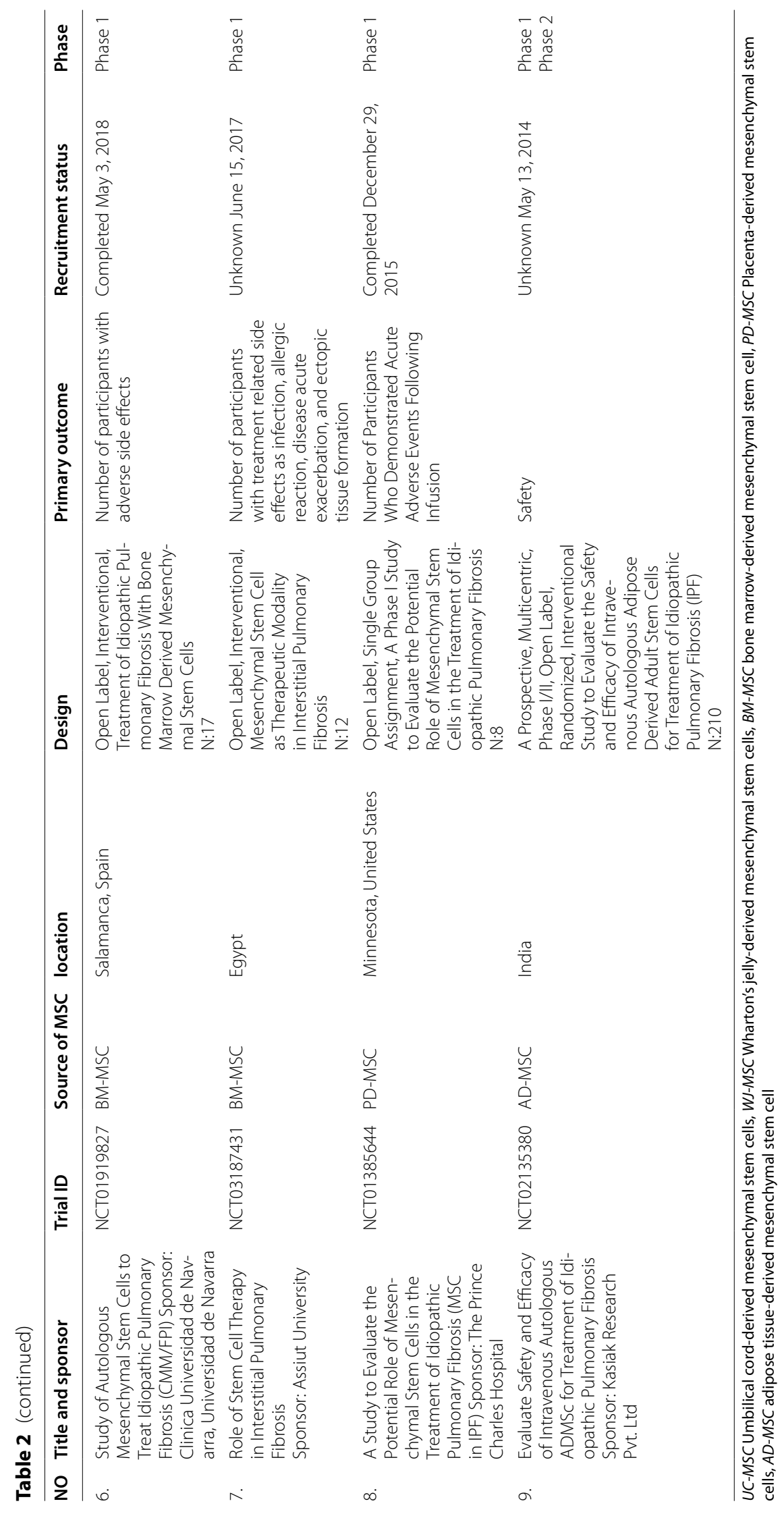


of mesenchymal stem cells, while many studies have suggested that a single MSC injection is safe for the patient and does not stimulate the immune system [138]. In addition, materials used to stimulate the growth and differentiation of these cells in the laboratory environment, including FBS, may elicit an immune response in the patient's body [139].

\section{Conclusion}

Wharton Jelly is a good source for extracting MSCs and applying it in the clinic. These cells have more stemness properties than other tissue-derived mesenchymal stem cells, and there are no ethical problems with using these MSCs. According to preclinical studies on mesenchymal stem cells derived from different sources in the pulmonary fibrosis model, it seems that Wharton jelly-derived cells could be excellent sources for the treatment of this disease in the future. Therefore, it is possible to open a clear perspective in the treatment of pulmonary fibrosis in the future by conducting more clinical trial studies using WJ-MSC. In the meantime, selecting the appropriate cell dose, the number of injections, injection method, precise protocols for isolation, cell culture, and the proliferation of these cells can be the beginning of a new treatment procedure in patients with pulmonary fibrosis in the future.

\begin{abstract}
Abbreviations
PF: Pulmonary fibrosis; IPF: Idiopathic pulmonary fibrosis; ATIl: Alveolar cell type 2; MSCs: Mesenchymal stem cells; PD-MSCs: Placenta-derived mesenchymal stem cells; HBM-MSC: Human bone marrow-derived mesenchymal stem cell; UC-MSC: Umbilical cord-derived mesenchymal stem cells; WJ-MSC: Wharton's jelly-derived mesenchymal stem cells; AD-MSC: Adipose tissuederived mesenchymal stem cell; HLA: Human leukocyte antigen; VEGF: Vascular endothelial growth factor; IGF-1: Insulin-like growth factor 1; bFGF: Basic fibroblast growth factor; NGF: Nerve growth factor; TGF-b1: Transforming growth beta-1; IFN- $\gamma$ : Interferon- $\gamma$; TNF-a: Tumor necrosis factor $a$; SFTPC: Surfactant protein C; IL-1 a: Interleukin-1 alpha; IL-10: Interleukin 10; IL-1B: Interleukin-1 beta; SDF-1/CXCL12: Stromal cell-derived factor 1; MCP 1/CCL2: Monocyte chemoattractant protein-1; HGF: Hepatocyte growth factor; PGE2: Prostaglandin E2; IDO: Indolamine 2, 3-dioxygenase; NK cell: Natural killer cells; PD-L1: Programmed death ligand 1; MMPs: Matrix metalloproteases; TIMPs: Tissue metalloproteinase inhibitors; EMT: Epithelial mesenchymal transport; CTD-IP: Interstitial pneumonia in connective tissue diseases; UIP-HLF: Usual interstitial pneumonia- Human primary lung fibroblasts; UC: Umbilical cord; VLA-4: Very late antigen 4; JAK: Janus kinase; BLM: Bleomycin; 6MWD: 6-Min walk distance; FVC: Forced vital capacity; DLCO: Diffusing capacity of lung for carbon monoxide.
\end{abstract}

\section{Acknowledgements}

Not applicable.

\section{Authors' contributions}

MS and ZFK contributed to the concept of the review. MS, ZFK and MK were responsible for the reference selection and writing of the manuscript. MS contributed to the critical review of the manuscript. All authors read and approved the final manuscript.

\section{Funding}

This work was supported by the Tehran University of Medical Sciences.
Availability of data and materials

Not applicable.

\section{Declarations}

Ethics approval and consent to participate

Not applicable.

\section{Consent for publication}

Not applicable.

\section{Competing interests}

The authors declare that they have no competing interests.

\section{Author details}

'Department of Applied Cell Sciences, School of Advanced Technologies in Medicine, Tehran University of Medical Sciences, Tehran, Iran. ${ }^{2}$ Department of Pulmonary and Critical Care, Shariati Hospital, Tehran University of Medical Sciences, Tehran, Iran.

Received: 10 December 2021 Accepted: 26 January 2022

Published online: 15 February 2022

\section{References}

1. Weibel ER, Klocke, Robert A, Heath, Donald Albert, Siebens AA, Elliott $\mathrm{DH}$, Burri PH, Beers MF, Cherniack NS. Human respiratory system. Encyclopedia Britannica, 13 Feb. 2020. https://www.britannica.com/science/ human-respiratory-system. Accessed 22 October 2021.

2. El Agha E, Kramann R, Schneider RK, Li X, Seeger W, Humphreys $\mathrm{BD}$, et al. Mesenchymal stem cells in fibrotic disease. Cell Stem Cell. 2017:21(2):166-77.

3. Distler JHW, Györfi A-H, Ramanujam M, Whitfield ML, Königshoff M, Lafyatis R. Shared and distinct mechanisms of fibrosis. Nat Rev Rheumatol. 2019;15(12):705-30.

4. Wynn TA. Common and unique mechanisms regulate fibrosis in various fibroproliferative diseases. J Clin Investig. 2007;117(3):524-9.

5. Wilson M, Wynn T. Pulmonary fibrosis: pathogenesis, etiology and regulation. Mucosal Immunol. 2009;2(2):103-21.

6. Herrera J, Henke CA, Bitterman PB. Extracellular matrix as a driver of progressive fibrosis. J Clin Investig. 2018;128(1):45-53.

7. Lynch DA, Sverzellati N, Travis WD, Brown KK, Colby TV, Galvin JR, et al. Diagnostic criteria for idiopathic pulmonary fibrosis: a Fleischner Society White Paper. Lancet Respir Med. 2018;6(2):138-53.

8. Raghu G, Rochwerg B, Zhang Y, Garcia CAC, Azuma A, Behr J, et al. An official ATS/ERS/JRS/ALAT clinical practice guideline: treatment of idiopathic pulmonary fibrosis. An update of the 2011 clinical practice guideline. Am J Resp Crit Care Med. 2015;192(2):e3-19.

9. Tomasek JJ, Gabbiani G, Hinz B, Chaponnier C, Brown RA. Myofibroblasts and mechano-regulation of connective tissue remodelling. Nat Rev Mol Cell Biol. 2002;3(5):349-63.

10. Raghu G, Collard HR, Egan JJ, Martinez FJ, Behr J, Brown KK, et al. An official ATS/ERS/JRS/ALAT statement: idiopathic pulmonary fibrosis: evidence-based guidelines for diagnosis and management. Am J Respir Crit Care Med. 2011;183(6):788-824.

11. Gribbin J, Hubbard RB, Le Jeune I, Smith CJ, West J, Tata LJ. Incidence and mortality of idiopathic pulmonary fibrosis and sarcoidosis in the UK. Thorax. 2006;61(11):980-5.

12. Raghu G, Narayanan A, Khalii N. Pathogenesis of idiopathic pulmonary fibrosis. UpTo Date. 2005;800:998-6374.

13. Wuyts WA, Agostini C, Antoniou KM, Bouros D, Chambers RC, Cottin $\checkmark$, et al. The pathogenesis of pulmonary fibrosis: a moving target. Eur Respir J. 2013:41(5):1207-18.

14. Zaman T, Lee JS. Risk factors for the development of idiopathic pulmonary fibrosis: a review. Curr Pulmonol Rep. 2018;7(4):118-25.

15. Naik PK, Moore BB. Viral infection and aging as cofactors for the development of pulmonary fibrosis. Expert Rev Respir Med. 2010;4(6):759-71. 
16. Ghatak S, Hascall VC, Rodriguez RM, Markwald RR, Misra S. Inflammation, wound healing, and fibrosis. Wound Healing: Stem Cells Repair and Restorations, Basic and Clinical Aspects. 2017;195.

17. Kolek V, Vašáková M, Šterclová M, Cwiertka K, Vrana D, Kudláček A, et al. Radiotherapy of lung Tumours in idiopathic pulmonary fibrosis. Klinicka onkologie: casopis Ceske a Slovenske onkologicke spolecnosti. 2017;30(4):303-6.

18. Paolocci G, Folletti I, Torén K, Ekström M, Dell'Omo M, Muzi G, et al. Occupational risk factors for idiopathic pulmonary fibrosis in Southern Europe: a case-control study. BMC Pulm Med. 2018;18(1):1-6.

19. Katzenstein A-LA, Myers JL. Idiopathic pulmonary fibrosis: Clinical relevance of pathologic classification. Am J Resp Crit Care Med. 1998;157(4):1301-15.

20. Thomas AQ, Lane K, Phillips J III, Prince M, Markin C, Speer M, et al. Heterozygosity for a surfactant protein $C$ gene mutation associated with usual interstitial pneumonitis and cellular nonspecific interstitial pneumonitis in one kindred. Am J Respir Crit Care Med. 2002;165(9):1322-8.

21. Sisson TH, Mendez M, Choi K, Subbotina N, Courey A, Cunningham A et al. Targeted injury of type II alveolar epithelial cells induces pulmonary fibrosis. Am J Respir Crit Care Med. 2010;181(3):254-63.

22. Selman M, Pardo A. Role of epithelial cells in idiopathic pulmonary fibrosis: from innocent targets to serial killers. Proc Am Thorac Soc. 2006;3(4):364-72.

23. Agostini C, Gurrieri C. Chemokine/cytokine cocktail in idiopathic pulmonary fibrosis. Proc Am Thorac Soc. 2006;3(4):357-63.

24. Prasse A, Pechkovsky DV, Toews GB, Jungraithmayr W, Kollert F, Goldmann T, et al. A vicious circle of alveolar macrophages and fibroblasts perpetuates pulmonary fibrosis via CCL18. Am J Respir Crit Care Med. 2006;173(7):781-92.

25. Locksley RM, Killeen N, Lenardo MJ. The TNF and TNF receptor superfamilies: integrating mammalian biology. Cell. 2001;104(4):487-501.

26. Sime PJ, Marr RA, Gauldie D, Xing Z, Hewlett BR, Graham FL, et al. Transfer of tumor necrosis factor-a to rat lung induces severe pulmonary inflammation and patchy interstitial fibrogenesis with induction of transforming growth factor- $\beta 1$ and myofibroblasts. Am J Pathol. 1998;153(3):825-32.

27. Zhang K, Gharaee-Kermani M, McGarry B, Remick D, Phan SH. TNFalpha-mediated lung cytokine networking and eosinophil recruitment in pulmonary fibrosis. J Immunol. 1997;158(2):954-9.

28. Khalil N, Xu YD, O'Connor R, Duronio V. Proliferation of pulmonary interstitial fibroblasts is mediated by transforming growth factor- $\beta 1$-induced release of extracellular fibroblast growth factor- 2 and phosphorylation of p38 MAPK and JNK. J Biol Chem. 2005;280(52):43000-9.

29. Ruiz V, Ordóñez RM, Berumen J, Ramirez R, Uhal B, Becerril C, et al. Unbalanced collagenases/TIMP-1 expression and epithelial apoptosis in experimental lung fibrosis. Am J Physiol Lung Cell Mol Physiol. 2003;285(5):L1026-36.

30. Zhang K, Gharaee-Kermani M, Jones ML, Warren JS, Phan SH. Lung monocyte chemoattractant protein-1 gene expression in bleomycininduced pulmonary fibrosis. J Immunol. 1994;153(10):4733-41.

31. Gharaee-Kermani M, McCullumsmith RE, Charo IF, Kunkel SL, Phan SH. CC-chemokine receptor 2 required for bleomycin-induced pulmonary fibrosis. Cytokine. 2003;24(6):266-76.

32. Ishida Y, Kimura A, Kondo T, Hayashi T, Ueno M, Takakura N, et al. Essential roles of the CC chemokine ligand 3-CC chemokine receptor 5 axis in bleomycin-induced pulmonary fibrosis through regulation of macrophage and fibrocyte infiltration. Am J Pathol. 2007;170(3):843-54.

33. Capelli A, Di Stefano A, Gnemmi I, Donner C. CCR5 expression and CC chemokine levels in idiopathic pulmonary fibrosis. Eur Respir J. 2005;25(4):701-7.

34. Suga M, lyonaga K, Ichiyasu H, Saita N, Yamasaki H, Ando M. Clinical significance of MCP-1 levels in BALF and serum in patients with interstitial lung diseases. Eur Respir J. 1999;14(2):376-82.

35. Chamberlain G, Fox J, Ashton B, Middleton J. Concise review: mesenchymal stem cells: their phenotype, differentiation capacity, immunological features, and potential for homing. Stem Cells. 2007;25(11):2739-49.

36. Ratajczak M, Zuba-Surma E, Kucia M, Reca R, Wojakowski W, Ratajczak J. The pleiotropic effects of the SDF-1-CXCR4 axis in organogenesis, regeneration and tumorigenesis. Leukemia. 2006;20(11):1915-24.
37. Musiał-Wysocka A, Kot M, Majka M. The pros and cons of mesenchymal stem cell-based therapies. Cell Transpl. 2019;28(7):801-12.

38. Ilancheran S, Moodley Y, Manuelpillai U. Human fetal membranes: a source of stem cells for tissue regeneration and repair? Placenta. 2009;30(1):2-10.

39. Yang ZX, Han Z-B, Ji YR, Wang YW, Liang L, Chi Y, et al. CD106 identifies a subpopulation of mesenchymal stem cells with unique immunomodulatory properties. PLoS ONE. 2013;8(3):e59354.

40. Abomaray F, Al Jumah M, Alsaad K, Jawdat D, Al Khaldi A, AlAskar A et al. Phenotypic and functional characterization of mesenchymal stem/multipotent stromal cells from decidua basalis of human term placenta. Stem Cells Int. 2016;2016.

41. Hsieh J-Y, Fu Y-S, Chang S-J, Tsuang Y-H, Wang H-W. Functional module analysis reveals differential osteogenic and stemness potentials in human mesenchymal stem cells from bone marrow and Wharton's jelly of umbilical cord. Stem Cells Dev. 2010;19(12):1895-910.

42. Troyer DL, Weiss ML. Concise review: Wharton's Jelly-derived cells are a primitive stromal cell population. Stem Cells. 2008;26(3):591-9.

43. Millán-Rivero JE, Nadal-Nicolás FM, García-Bernal D, Sobrado-Calvo P, Blanquer M, Moraleda JM, et al. Human Wharton's jelly mesenchymal stem cells protect axotomized rat retinal ganglion cells via secretion of anti-inflammatory and neurotrophic factors. Sci Rep. 2018;8(1):1-14.

44. Liau L, Ruszymah B, Ng M, Law J. Characteristics and clinical applications of Wharton's jelly-derived mesenchymal stromal cells. Curr Res Transl Med. 2020;68(1):5-16.

45. Subramanian A, Fong C-Y, Biswas A, Bongso A. Comparative characterization of cells from the various compartments of the human umbilical cord shows that the Wharton's jelly compartment provides the best source of clinically utilizable mesenchymal stem cells. PLoS ONE. 2015;10(6):e0127992.

46. Richardson SM, Kalamegam G, Pushparaj PN, Matta C, Memic A, Khademhosseini $A$, et al. Mesenchymal stem cells in regenerative medicine: focus on articular cartilage and intervertebral disc regeneration. Methods. 2016;99:69-80.

47. Stolzing A, Jones E, Mcgonagle D, Scutt A. Age-related changes in human bone marrow-derived mesenchymal stem cells: consequences for cell therapies. Mech Ageing Dev. 2008;129(3):163-73.

48. Wagner W, Bork S, Horn P, Krunic D, Walenda T, DiehImann A, et al Aging and replicative senescence have related effects on human stem and progenitor cells. PLoS ONE. 2009;4(6):e5846.

49. Rhee K-J, Lee Jl, Eom YW. Mesenchymal stem cell-mediated effects of tumor support or suppression. Int J Mol Sci. 2015;16(12):30015-33.

50. Yoo KH, Jang IK, Lee MW, Kim HE, Yang MS, Eom Y, et al. Comparison of immunomodulatory properties of mesenchymal stem cells derived from adult human tissues. Cell Immunol. 2009;259(2):150-6.

51. Stefańska K, Ożegowska K, Hutchings G, Popis M, Moncrieff L, Dompe C, et al. Human Wharton's jelly — cellular specificity, stemness potency, animal models, and current application in human clinical trials. J Clin Med. 2020;9(4):1102.

52. Deuse T, Stubbendorff M, Tang-Quan K, Phillips N, Kay MA, Eiermann T, et al. Immunogenicity and immunomodulatory properties of umbilical cord lining mesenchymal stem cells. Cell Transpl. 2011;20(5):655-67.

53. Zhou C, Yang B, Tian Y, Jiao H, Zheng W, Wang J, et al. Immunomodulatory effect of human umbilical cord Wharton's jelly-derived mesenchymal stem cells on lymphocytes. Cell Immunol. 2011;272(1):33-8.

54. Weiss ML, Anderson C, Medicetty S, Seshareddy KB, Weiss RJ, VanderWerff I, et al. Immune properties of human umbilical cord Wharton's jelly-derived cells. Stem Cells. 2008;26(11):2865-74.

55. Deng Y, Yi S, Wang G, Cheng J, Zhang Y, Chen W, et al. Umbilical cordderived mesenchymal stem cells instruct dendritic cells to acquire tolerogenic phenotypes through the IL-6-mediated upregulation of SOCS1. Stem Cells Dev. 2014;23(17):2080-92.

56. Paladino FV, Sardinha LR, Piccinato CA, Goldberg AC. Intrinsic variability present in Wharton's jelly mesenchymal stem cells and T cell responses may impact cell therapy. Stem Cells Int. 2017;2017.

57. Donders R, Bogie JF, Ravanidis S, Gervois P, Vanheusden M, Maree R, et al. Human Wharton's Jelly-derived stem cells display a distinct immunomodulatory and proregenerative transcriptional signature compared to bone marrow-derived stem cells. Stem Cells Dev. 2018;27(2):65-84.

58. Danchuk S, Ylostalo JH, Hossain F, Sorge R, Ramsey A, Bonvillain RW, et al. Human multipotent stromal cells attenuate 
lipopolysaccharide-induced acute lung injury in mice via secretion of tumor necrosis factor-a-induced protein 6. Stem Cell Res Ther. 2011;2(3):1-15.

59. Fang X, Neyrinck AP, Matthay MA, Lee JW. Allogeneic human mesenchymal stem cells restore epithelial protein permeability in cultured human alveolar type II Cells by SECRETION OF ANGIOPOIETIN-1* Biol Chem. 2010;285(34):26211-22.

60. Mei SHJ, McCarter SD, Deng Y, Parker CH, Liles WC, Stewart DJ. Prevention of LPS-induced acute lung injury in mice by mesenchymal stem cells overexpressing angiopoietin 1. PLoS Med. 2007:4(9):e269.

61. Krasnodembskaya A, Song Y, Fang X, Gupta N, Serikov V, Lee JW, et al. Antibacterial effect of human mesenchymal stem cells is mediated in part from secretion of the antimicrobial peptide LL-37. Stem Cells. 2010;28(12):2229-38.

62. Gupta N, Krasnodembskaya A, Kapetanaki M, Mouded M, Tan X, Serikov $V$, et al. Mesenchymal stem cells enhance survival and bacterial clearance in murine Escherichia coli pneumonia. Thorax. 2012;67(6):533-9.

63. Monsel A, Zhu Y-G, Gennai S, Hao Q, Hu S, Rouby J-J, et al. Therapeutic effects of human mesenchymal stem cell-derived microvesicles in severe pneumonia in mice. Am J Res Crit Care Med. 2015;192(3):324-36.

64. Hao Q, Gudapati V, Monsel A, Park JH, Hu S, Kato H, et al. Mesenchymal stem cell-derived extracellular vesicles decrease lung injury in mice. J Immunol. 2019;203(7):1961-72.

65. Choi H, Lee RH, Bazhanov N, Oh JY, Prockop DJ. Anti-inflammatory protein TSG-6 secreted by activated MSCs attenuates zymosan-induced mouse peritonitis by decreasing TLR2/NF-KB signaling in resident macrophages. Blood. 2011;118(2):330-8.

66. Prockop DJ, Oh JY. Mesenchymal stem/stromal cells (MSCs): role as guardians of inflammation. Mol Ther. 2012;20(1):14-20.

67. Oh JY, Roddy GW, Choi H, Lee RH, Ylöstalo JH, Rosa RH, et al. Antiinflammatory protein TSG-6 reduces inflammatory damage to the cornea following chemical and mechanical injury. Proc Natl Acad Sci. 2010;107(39):16875-80.

68. Dyer DP, Thomson JM, Hermant A, Jowitt TA, Handel TM, Proudfoot AE, et al. TSG-6 inhibits neutrophil migration via direct interaction with the chemokine CXCL8. J Immunol. 2014;192(5):2177-85.

69. Wojtan P, Mierzejewski M, Osińska I, Domagała-Kulawik J. Macrophage polarization in interstitial lung diseases. Central-Eur J Immunol. 2016;41(2):159.

70. Byrne AJ, Mathie SA, Gregory LG, Lloyd CM. Pulmonary mac rophages: key players in the innate defence of the airways. Thorax. 2015;70(12):1189-96.

71. Gharib SA, Johnston LK, Huizar I, Birkland TP, Hanson J, Wang Y, et al. MMP28 promotes macrophage polarization toward M2 cells and augments pulmonary fibrosis. J Leukoc Biol. 2014;95(1):9-18.

72. Medbury H, James V, Ngo J, Hitos K, Wang Y, Harris D, et al. Differing association of macrophage subsets with atherosclerotic plaque stability. Int Angiol. 2013;32(1):74-84.

73. Ionescu L, Byrne RN, van Haaften T, Vadivel A, Alphonse RS, Rey-Parra $\mathrm{GJ}$, et al. Stem cell conditioned medium improves acute lung injury in mice: in vivo evidence for stem cell paracrine action. Am J Physiol-Lung Cell Mol Physiol. 2012;303(11):L967-77.

74. Asami T, Ishii M, Namkoong H, Yagi K, Tasaka S, Asakura T, et al. Anti-inflammatory roles of mesenchymal stromal cells during acute Streptococcus pneumoniae pulmonary infection in mice. Cytotherapy. 2018;20(3):302-13.

75. Lim J-Y, Im K-I, Lee E-S, Kim N, Nam Y-S, Jeon Y-W, et al. Enhanced immunoregulation of mesenchymal stem cells by IL-10-producing type 1 regulatory T cells in collagen-induced arthritis. Sci Rep. 2016;6(1):1-13.

76. Serrano-Mollar A. Cell therapy in idiopathic pulmonary fibrosis. Med Sci. 2018;6(3):64.

77. Chuang H-M, Shih TE, Lu K-Y, Tsai S-F, Harn H-J, Ho L-I. Mesenchymal stem cell therapy of pulmonary fibrosis: improvement with target combination. Cell Transplant. 2018;27(11):1581-7.

78. Königshoff M, Kramer M, Balsara N, Wilhelm J, Amarie OV, Jahn A, et al. WNT1-inducible signaling protein-1 mediates pulmonary fibrosis in mice and is upregulated in humans with idiopathic pulmonary fibrosis. J Clin Investig. 2009;119(4):772-87.

79. Koli K, Myllärniemi M, Vuorinen K, Salmenkivi K, Ryynänen MJ, Kinnula VL, et al. Bone morphogenetic protein-4 inhibitor gremlin is overexpressed in idiopathic pulmonary fibrosis. Am J Pathol. 2006;169(1):61-71.

80. Selman M, King TE Jr, Pardo A. Idiopathic pulmonary fibrosis: prevailing and evolving hypotheses about its pathogenesis and implications for therapy. Ann Intern Med. 2001;134(2):136-51.

81. Smith JN, Witkin MD, Jogasuria AP, Christo KF, Raffay TM, Markowitz SD, et al. Therapeutic targeting of 15-PGDH in murine pulmonary fibrosis. Sci Rep. 2020;10(1):1-10.

82. Maher TM, Evans IC, Bottoms SE, Mercer PF, Thorley AJ, Nicholson $A G$, et al. Diminished prostaglandin E2 contributes to the apoptosis paradox in idiopathic pulmonary fibrosis. Am J Respir Crit Care Med. 2010;182(1):73-82.

83. Borok Z, Gillissen A, Buhl R, Hoyt RF, Hubbard RC, Ozaki T, et al. Augmentation of functional prostaglandin $E$ levels on the respiratory epithelial surface by aerosol administration of prostaglandin E. Am Rev Respir Dis. 1991;144(5):1080-4

84. Jandl K, Kwapiszewska G. Stiffness of the extracellular matrix: a regulator of prostaglandins in pulmonary fibrosis? American Thoracic Society; 2020.

85. Desai O, Winkler J, Minasyan M, Herzog EL. The role of immune and inflammatory cells in idiopathic pulmonary fibrosis. Front Med. 2018:5:43.

86. Pellicoro A, Ramachandran P, Iredale JP, Fallowfield JA. Liver fibrosis and repair: immune regulation of wound healing in a solid organ. Nat Rev Immunol. 2014;14(3):181-94.

87. Huang E, Peng N, Xiao F, Hu D, Wang X, Lu L. The roles of immune cells in the pathogenesis of fibrosis. Int J Mol Sci. 2020;21(15):5203.

88. Morimoto Y, Hirahara K, Kiuchi M, Wada T, Ichikawa T, Kanno T, et al. Amphiregulin-producing pathogenic memory Thelper 2 cells instruct eosinophils to secrete osteopontin and facilitate airway fibrosis. Immunity. 2018:49(1):134-50. e6.

89. Gordon S, Plüddemann A, Martinez EF. Macrophage heterogeneity in tissues: phenotypic diversity and functions. Immunol Rev. 2014;262(1):36-55.

90. Buckley S, Shi W, Barsky L, Warburton D. TGF- $\beta$ signaling promotes survival and repair in rat alveolar epithelial type 2 cells during recovery after hyperoxic injury. Am J Physiol-Lung Cell Mol Physiol. 2008;294(4):L739-48.

91. Bartram U, Speer CP. The role of transforming growth factor $\beta$ in lung development and disease. Chest. 2004;125(2):754-65.

92. Andrew L, David J. TGF- $\beta$-signaling and the fibrotic response. FASEB J. 2004:18(7):816.

93. Liu M, Zeng X, Wang J, Fu Z, Wang J, Liu M, et al. Immunomodulation by mesenchymal stem cells in treating human autoimmune diseaseassociated lung fibrosis. Stem Cell Res Ther. 2016;7(1):1-15.

94. Kim HY, Kim HJ, Min HS, Kim S, Park WS, Park SH, et al. NKT cells promote antibody-induced joint inflammation by suppressing transforming growth factor beta1 production. J Exp Med. 2005;201(1):41-7.

95. Qi M-Y, Liu H-R, Su Y-h, Yu S-Q. Protective effect of Icariin on the early stage of experimental diabetic nephropathy induced by streptozotocin via modulating transforming growth factor $\beta 1$ and type IV collagen expression in rats. J Ethnopharmacol. 2011;138(3):731-6.

96. Wynn RF, Hart CA, Corradi-Perini C, O'Neill L, Evans CA, Wraith JE, et al. A small proportion of mesenchymal stem cells strongly expresses functionally active CXCR4 receptor capable of promoting migration to bone marrow. Blood. 2004;104(9):2643-5.

97. Sackstein R, Merzaban JS, Cain DW, Dagia NM, Spencer JA, Lin CP, et al. Ex vivo glycan engineering of CD44 programs human multipotent mesenchymal stromal cell trafficking to bone. Nat Med. 2008;14(2):181-7.

98. Henschler R, Deak E, Seifried E. Homing of mesenchymal stem cells. Transfus Med Hemother. 2008;35(4):306-12.

99. He F, Wang Y, Li Y, Yu L. Human amniotic mesenchymal stem cells alleviate paraquat-induced pulmonary fibrosis in rats by inhibiting the inflammatory response. Life Sci. 2020;243:117290.

100. de Castro LL, Lopes-Pacheco M, Weiss DJ, Cruz FF, Rocco PRM. Current understanding of the immunosuppressive properties of mesenchymal stromal cells. J Mol Med. 2019;97(5):605-18.

101. Ni K, Liu M, Zheng J, Wen L, Chen Q, Xiang Z, et al. PD-1/PD-L1 pathway mediates the alleviation of pulmonary fibrosis by human mesenchymal stem cells in humanized mice. Am J Respir Cell Mol Biol. 2018:58(6):684-95. 
102. Luo X-Y, Meng X-J, Cao D-C, Wang W, Zhou K, Li L, et al. Transplantation of bone marrow mesenchymal stromal cells attenuates liver fibrosis in mice by regulating macrophage subtypes. Stem Cell Res Ther. 2019;10(1):1-11.

103. Willis GR, Fernandez-Gonzalez A, Anastas J, Vitali SH, Liu X, Ericsson M, et al. Mesenchymal stromal cell exosomes ameliorate experimental bronchopulmonary dysplasia and restore lung function through macrophage immunomodulation. Am J Respir Crit Care Med. 2018;197(1):104-16.

104. Munir H, Luu N-T, Clarke LS, Nash GB, McGettrick HM. Comparative ability of mesenchymal stromal cells from different tissues to limit neutrophil recruitment to inflamed endothelium. PLoS ONE. 2016;11(5):e0155161.

105. Anzalone R, lacono ML, Corrao S, Magno F, Loria T, Cappello F, et al. New emerging potentials for human Wharton's jelly mesenchymal stem cells: immunological features and hepatocyte-like differentiative capacity. Stem Cells Dev. 2010;19(4):423-38.

106. Palka J, Bańkowski E, Jaworski S. An accumulation of IGF-1 and IGF-binding proteins in human umbilical cord. Mol Cell Biochem. 2000:206(1):133-9.

107. Rao CV, Li X, Toth P, Lei ZM. Expression of epidermal growth factor transforming growth factor-alpha, and their common receptor genes in human umbilical cords. J Clin Endocrinol Metab. 1995;80(3):1012-20.

108. Moodley Y, Atienza D, Manuelpillai U, Samuel CS, Tchongue J, llancheran $\mathrm{S}$, et al. Human umbilical cord mesenchymal stem cells reduce fibrosis of bleomycin-induced lung injury. Am J Pathol. 2009;175(1):303-13.

109. Carraro G, Perin L, Sedrakyan S, Giuliani S, Tiozzo C, Lee J, et al. Human amniotic fluid stem cells can integrate and differentiate into epithelial lung lineages. Stem Cells. 2008;26(11):2902-11.

110. Abdel Halim AS, Ahmed HH, Aglan HA, Abdel Hamid FF, Mohamed MR. Role of bone marrow-derived mesenchymal stem cells in alleviating pulmonary epithelium damage and extracellular matrix remodeling in a rat model of lung fibrosis induced by amiodarone. Biotech Histochem. 2021;96(6):418-30.

111. Chambers DC, Enever D, llic N, Sparks L, Whitelaw K, Ayres J, et al. A phase $1 \mathrm{~b}$ study of placenta-derived mesenchymal stromal cells in patients with idiopathic pulmonary fibrosis. Respirology. 2014:19(7):1013-8.

112. Saleh M, Vaezi AA, Aliannejad R, Sohrabpour AA, Kiaei SZF, Shadnoush $M$, et al. Cell therapy in patients with COVID-19 using Wharton's jelly mesenchymal stem cells: a phase 1 clinical trial. Stem Cell Res Ther. 2021;12(1):410.

113. Chen J, Si L, Zhou L, Deng Y. Role of bone marrow mesenchymal stem cells in the development of PQ-induced pulmonary fibrosis. Mol Med Rep. 2019;19(4):3283-90

114. Periera-Simon S, Xia X, Catanuto P, Coronado R, Kurtzberg J, Bellio $M$, et al. Anti-fibrotic effects of different sources of MSC in bleomycin-induced lung fibrosis in C57BL6 male mice. Respirology. 2021;26(2):161-70.

115. Moroncini G, Paolini C, Orlando F, Capelli C, Grieco A, Tonnini C, et al. Mesenchymal stromal cells from human umbilical cord prevent the development of lung fibrosis in immunocompetent mice. PLOS ONE. 2018;13(6):e0196048

116. Chen $X$, Wu Y, Wang Y, Chen L, Zheng W, Zhou S, et al. Human menstrual blood-derived stem cells mitigate bleomycin-induced pulmonary fibrosis through anti-apoptosis and anti-inflammatory effects. Stem Cell Res Ther. 2020;11(1):1-19.

117. Chu K-A, Wang S-Y, Yeh C-C, Fu T-W, Fu Y-Y, Ko T-L, et al. Reversal of bleomycin-induced rat pulmonary fibrosis by a xenograft of human umbilical mesenchymal stem cells from Wharton's jelly. Theranostics. 2019;9(22):6646

118. Tashiro J, Elliot SJ, Gerth DJ, Xia X, Pereira-Simon S, Choi R, et al. Therapeutic benefits of young, but not old, adipose-derived mesenchymal stem cells in a chronic mouse model of bleomycin-induced pulmonary fibrosis. Transl Res. 2015;166(6):554-67.

119. Li D-Y, Li R-F, Sun D-X, Pu D-D, Zhang Y-H. Mesenchymal stem cell therapy in pulmonary fibrosis: a meta-analysis of preclinical studies. Stem Cell Res Ther. 2021;12(1):1-11.

120. Chua F, Gauldie J, Laurent GJ. Pulmonary fibrosis: searching for model answers. Am J Respir Cell Mol Biol. 2005:33(1):9-13.
121. Moeller A, Ask K, Warburton D, Gauldie J, Kolb M. The bleomycin animal model: A useful tool to investigate treatment options for idiopathic pulmonary fibrosis? Int J Biochem Cell Biol. 2008;40(3):362-82.

122. Tashiro J, Rubio GA, Limper AH, Williams K, Elliot SJ, Ninou I, et al. Exploring animal models that resemble idiopathic pulmonary fibrosis. Front Med. 2017;4:118.

123. Sueblinvong V, Neujahr DC, Mills ST, Roser-Page S, Guidot D, Rojas $M$, et al. Predisposition for disrepair in the aged lung. Am J Med Sci. 2012:344(1):41-51.

124. Kavianpour M, Saleh M, Verdi J. The role of mesenchymal stromal cells in immune modulation of COVID-19: focus on cytokine storm. Stem Cell Res Ther. 2020;11(1):1-19.

125. Harrell CR, Sadikot R, Pascual J, Fellabaum C, Jankovic MG, Jovicic N, et al. Mesenchymal stem cell-based therapy of inflammatory lung diseases: current understanding and future perspectives. Stem Cells Int. 2019;2019.

126. Tsuchiya A, Kojima Y, Ikarashi S, Seino S, Watanabe Y, Kawata Y, et al. Clinical trials using mesenchymal stem cells in liver diseases and inflammatory bowel diseases. Inflamm Regen. 2017;37(1):1-15.

127. Tzouvelekis A, Paspaliaris V, Koliakos G, Ntolios P, Bouros E, Oikonomou $A$, et al. A prospective, non-randomized, no placebo-controlled, phase Ib clinical trial to study the safety of the adipose derived stromal cellsstromal vascular fraction in idiopathic pulmonary fibrosis. J Transl Med. 2013;11(1):1-13.

128. Campo A, González-Ruiz JM, Andreu E, Alcaide AB, Ocón MM, De-Torres $J$, et al. Endobronchial autologous bone marrow-mesenchymal stromal cells in idiopathic pulmonary fibrosis: a phase I trial. ERJ Open Res. 2021;7(2)

129. Glassberg MK, Minkiewicz J, Toonkel RL, Simonet ES, Rubio GA, DiFede $D$, et al. Allogeneic human mesenchymal stem cells in patients with idiopathic pulmonary fibrosis via intravenous delivery (AETHER): a phase I safety clinical trial. Chest. 2017;151(5):971-81.

130. Averyanov A, Koroleva I, Konoplyannikov M, Revkova V, Lesnyak V, Kalsin $V$, et al. First-in-human high-cumulative-dose stem cell therapy in idiopathic pulmonary fibrosis with rapid lung function decline. Stem Cells Transl Med. 2020:9(1):6-16.

131. Bellagamba BC, Abreu BRRd, Grivicich I, Markarian CF, Camassola M, Nardi NB, et al. Human mesenchymal stem cells are resistant to cytotoxic and genotoxic effects of cisplatin in vitro. Genet Mol Biol. 2016:39:129-34.

132. Hatzistergos KE, Blum A, Ince TA, Grichnik JM, Hare JM. What is the oncologic risk of stem cell treatment for heart disease? Am Heart Assoc: 2011. p. 1300-3

133. Yubo M, Yanyan L, Li L, Tao S, Bo L, Lin C. Clinical efficacy and safety of mesenchymal stem cell transplantation for osteoarthritis treatment: a meta-analysis. PLoS ONE. 2017;12(4):e0175449.

134. Herberts CA, Kwa MS, Hermsen HP. Risk factors in the development of stem cell therapy. JTransl Med. 2011;9(1):1-14.

135. Wang Y, Chen X, Cao W, Shi Y. Plasticity of mesenchymal stem cells in immunomodulation: pathological and therapeutic implications. Nat Immunol. 2014:15(11):1009-16.

136. Von Bahr L, Batsis I, Moll G, Hägg M, Szakos A, Sundberg B, et al. Analysis of tissues following mesenchymal stromal cell therapy in humans indicates limited long-term engraftment and no ectopic tissue formation. Stem Cells. 2012:30(7):1575-8

137. Mäkelä T, Takalo R, Arvola O, Haapanen H, Yannopoulos F, Blanco $\mathrm{R}$, et al. Safety and biodistribution study of bone marrow-derived mesenchymal stromal cells and mononuclear cells and the impact of the administration route in an intact porcine model. Cytotherapy. 2015:17(4):392-402

138. Cho PS, Messina DJ, Hirsh EL, Chi N, Goldman SN, Lo DP, et al. Immunogenicity of umbilical cord tissue-derived cells. Blood. 2008:111(1):430-8.

139. Von Bonin M, Stölzel F, Goedecke A, Richter K, Wuschek N, Hölig $\mathrm{K}$, et al. Treatment of refractory acute GVHD with third-party MSC expanded in platelet lysate-containing medium. Bone Marrow Transpl. 2009:43(3):245-51.

\section{Publisher's Note}

Springer Nature remains neutral with regard to jurisdictional claims in published maps and institutional affiliations. 